\title{
Altered lectin-binding sites in normal colon and ulcerative colitis
}

\author{
Alteração dos sítios de ligação da lectina no cólon normal e na colite ulcerativa
}

Mario R. Melo-Júnior'; Adriana M. S. Telles²; Francisco E. B. Albuquerque ${ }^{3}$; Nicodemos T. Pontes-Filho'; Luiz B. Carvalho Jr.; Eduardo I. C. Beltrão ${ }^{5}$

\begin{tabular}{|c|c|}
\hline & \\
\hline $\begin{array}{l}\text { Ulcerative colitis } \\
\text { Lectin histochemistry } \\
\text { Image analysis } \\
\text { Diagnosis }\end{array}$ & 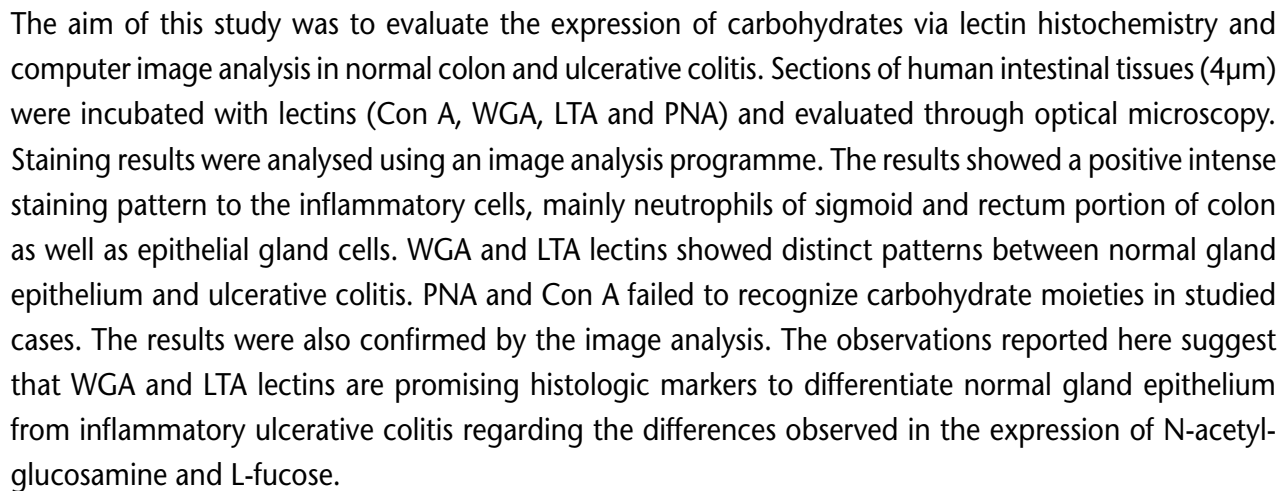 \\
\hline
\end{tabular}

\section{resumo}

O presente trabalho objetivou, através de histoquímica com lectinas e análise digital de imagens, avaliar a expressão de carboidratos em amostras de colo normal e com colite ulcerativa. A partir de fragmentos de mucosa intestinal foram obtidos cortes histológicos $(4 \mu m)$ que foram incubados com lectinas (Con A, WGA, LTA e PNA), e os resultados das marcações foram avaliados através de microscopia óptica e sistema de análise de imagens. Os resultados obtidos revelaram uma intensa marcação para as células inflamatórias, principalmente neutrófilos infiltrados no tecido de reto e sigmóide, bem como células das glândulas intestinais. As lectinas WGA e LTA exibiram padrões distintos de marcação entre o epitélio normal e os casos de colite ulcerativa. As lectinas PNA e Con A falharam em reconhecer os carboidratos celulares nos casos estudados em ambos os grupos. Os resultados obtidos foram confirmados pela análise de imagem. As observações obtidas sugerem que as lectinas WGA e LTA são marcadores promissores para diferenciar o epitélio normal do padrão inflamatório da colite ulcerativa, indicando uma expressão distinta de N-acetilglicosamina e L-fucose nos respectivos casos estudados.

\section{unitermos}

Colite ulcerativa

Histoquimica com lectinas

Análise digital de imagens

Diagnóstico

\footnotetext{
1. Mestre em Anatomia Patológica, Centro de Ciências da Saúde da Universidade Federal de Pernambuco (CCS/UFPE).

2. Professor-adjunto do Departamento de Patologia do CCS/UFPE.

3. Professor-adjunto do Departamento de Cirurgia do CCS/UFPE.

4. Professor-titular do Departamento de Bioquímica do Centro de Ciências Biológicas da UFPE.

5. Doutor em Ciências Biológicas, Laboratório de Imunopatologia Keizo Asami (Lika)/UFPE.
} 
The inflammatory bowel diseases, Crohn's disease and ulcerative colitis are complex multifactorial traits involving environmental, genetic and pathobiochemical factors ${ }^{(11,14)}$.

Ulcerative colitis is associated with abnormalities of mucin synthesis and secretion, features that may also be associated with malignant changes ${ }^{(8)}$, alterations in the metabolism of lipids, carbohydrates and proteins, leading to injuries in tissues ${ }^{(9)}$.

Glycoconjugates are integral components of cell membrane and act as receptors of different compounds (e.g., lectins, antibodies, galectins) and regulate cellto-cell interactions. The stage of differentiation and maturity of a cell is reflected in the structure of cell-surface glycoconjugates ${ }^{(6,17)}$. Carbohydrates are mainly found in glycoproteins and glycolipids presenting a high complexity and structural variability. They also function as signals in cells which have undergone alterations ${ }^{(13)}$.

Lectins are (glyco)proteins that recognize carbohydrates. Lectin-binding patterns are altered as response of changes in glycoproteins expression accompanying cell maturation and/or disease $\mathrm{e}^{(1,16,18)}$.

In histochemistry lectins have been used as tissue markers under neoplastic transformation ${ }^{(2)}$. Lectin binding to human colonocytes can predict malignant and premalignant lesions of colon and has potential as a non-invasive screening tool for colorectal neoplasms ${ }^{(5)}$.

In this study we evaluated the composition of carbohydrates in cell surface using lectin histochemistry and computer image analysis in intestinal biopsies of normal colon $(n=6)$ and ulcerative colitis $(n=7)$. Surgical specimens $\left( \pm 0.3 \mathrm{~cm}^{2}\right)$ were obtained from different patients of both sexes (mean age: 55 years old). Biopsies were fixed in buffered formalin, processed according to routine laboratory procedure and embedded in paraffin. Tissues section $(4 \mu \mathrm{m})$ were adhered to albumin-treated glass slides and kept at $35^{\circ} \mathrm{C}$ until use. Haematoxylin and eosin staining was used for diagnosis.

Lectin histochemistry was developed using Concanavalin $A($ Con $A)$, wheat germ agglutinin (WGA), Lotus tetragonolobus agglutinin (LTA) and peanut agglutinin (PNA) conjugated to peroxidase (Sigma Chemical Company, USA). Slices were deparaffinized in xylene and hydrated through graded alcohol. Tissue sections were treated with $0.1 \%$ $(\mathrm{w} / \mathrm{v})$ trypsin solution, followed by $0.3 \%(\mathrm{v} / \mathrm{v})$ methanolic hydrogen peroxide solution and incubated with the lectins (Con A, $50 \mu \mathrm{g} / \mathrm{mL}$; WGA, LTA and PNA, $25 \mu \mathrm{g} / \mathrm{mL}$ ) for two hours. Peroxidase was visualized with diaminobenzidine
(DAB) and hydrogen peroxide in PBS. Tissue sections were counterstained with haematoxylin and evaluated through optical microscopy. Lectin-binding inhibition assays were performed using the corresponding lectin-specific sugar: methyl- $\alpha$-D-mannoside, $\mathrm{N}$-acetylglucosamine, $\mathrm{D}$-galactose and L-fucose for Con A, WGA, PNA and LTA, respectively, at final concentration of $300 \mathrm{mM}$.

Images of histological slices were captured using a digital video camera (Sony-USA) connected to a microscope and were processed using the Optimas ${ }^{\mathrm{TM}} 6.1$ (Optimas Corporation, USA) image analysis programme. Lectinbinding patterns were used to calculate the mean area of stained cells $\left(\mu \mathrm{m}^{2}\right)$ and the mean number of cells ${ }^{(15)}$. Semiquantitative optical analysis was carried out taking account the intensity $(I)$, indicated as weak $(+)$, moderate $(++)$ or intense (+++), according to Özer et al. ${ }^{(10)}$.

Our results showed an intense positive staining pattern to inflammatory cells, mainly neutrophils, of sigmoid and rectum portion of colon as well as epithelial gland cells. PNA and Con A failed to recognize carbohydrate moieties in the studied cases. WGA and LTA showed distinct patterns between normal gland epithelium and inflammatory tissue pattern of ulcerative colitis. In ulcerative colitis, WGA binding was observed in the gland cells of intestinal crypts while PNA recognized the inflammatory cells; in both cases the binding pattern was intense. Normal glands were weakly recognized by LTA (Table). Image analysis of ulcerative colitis showed that a higher number of cells were recognized by LTA $(19.78 \pm 4.08)$ followed by WGA $(18.23 \pm 3.25)$. The same profile was observed for the mean area, $18.26 \pm 5.02$ and $15.08 \pm 4.14$, respectively for LTA and WGA. Image analysis for normal gland was coherent with the results observed in lectin histochemistry method. Unspecific inflammations were also recognized by WGA and LTA (weak intensity) but not by Con A and PNA. The results of image analysis confirmed the semi-quantitative results observed for these samples.

Lectin histochemistry of the ulcerative colitis and normal

Table gland epithelium

\section{Lectin staining patterns}

Con $A^{\mathrm{a}} \quad$ WGA ${ }^{\mathrm{b}} \quad$ LTA $^{\mathrm{b}} \quad$ PNA $^{\mathrm{b}}$

Normal gland $(n=6)$

Ulcerative colitis $(n=7)$

none (-); weak (+); moderate (++); intense (+++); a: $50 \mu \mathrm{g} / \mathrm{ml} ; b: 25 \mu \mathrm{g} / \mathrm{ml}$. 
Preliminary experiments with normal and diseased intestinal tissues exhibited differential lectin-binding patterns ${ }^{(3,12)}$ as observed in our study. The increasing PNA binding from unspecific inflammations up to colorectal carcinomas was already observed. In contrast to normal colon and colorectal mucosa, PNA reactive glycoconjugates are commonly expressed in most colorectal carcinomas and in some pre-malignant conditions such as adenomas and ulcerative colitis ${ }^{(7)}$. Changes in carbohydrate moieties of glycoconjugates in ulcerative colitis and Crohn's disease are associated with increased risk for colorectal cancer. Consequences of these changes may be relevant not only for cell-surface glycoconjugates but also for intracellular glycoconjugates ${ }^{(4)}$.

Our findings are in accordance with those observations. In this study WGA also presented a recognition pattern for diseased tissues. Our results indicate differences in the carbohydrate expression. $\mathrm{N}$-acetylglucosamine was absent or not accessible, for lectin recognition, in normal tissues, as well as mannosides and galactose. L-fucose was found in the intestinal crypts of normal glands. WGA and LTA indicated a high expression of $\mathrm{N}$-acetylglucosamine in gland cells in ulcerative colitis; and L-fucose, in inflammatory cells in ulcerative colitis and gland cells in the normal counterpart.

The results reported here indicate differences in the expression of $\mathrm{N}$-acetylglucosamine and L-fucose in normal and sick tissues and suggest that WGA and LTA lectins are promising histological markers to differentiate normal gland epithelium from inflammatory tissue of ulcerative colitis.

\section{Acknowledgments}

This work was supported by CNPq (CTPetro $\mathrm{n}^{\circ}$ 463655/001). The authors thank Carmelita de Lima Bezerra Cavalcanti for technical assistance.

\section{References}

I. BELTRÃO, E. I. C. et al. Parkia pendula lectin as histochemistry marker for meningothelial tumor. Eur J Histochem, v. 47, n. 2, p. 139-42, 2003.

2. BROOKS, A. S. The involvement of Helix pomatia lectin (HPA) binding $\mathrm{N}$-acetylgalactosamine glycan in cancer progression. Histol Histopathol, v. I5, n. I, p. I43-58, 2000.

3. CAMPBELL, B. J. et al. Direct demonstration of increased expression of Thomsen-Friedenreich (TF) antigen in colonic adenocarcinoma and ulcerative colitis mucin and its concealment in normal mucin. J Clin Invest, v. 95, p. 57I -6, 1995.

4. CAMPBEL, B. J. et al. Altered glycosilation in inflammatory bowel disease: a possible role in cancer development. Glyconjug J, v. |8, n. | |- |2, p. 85|-8, 200।.

5. DESILETS, D.J. et al. Lectin binding to human colonocytes is predictive of colonic neoplasia. Am J Gastroenterol, v. 94, n. 3, p. 744-50, 1999.

6. JENSEN-JAROLIM, E. et al. The constitutive expression of galectin-3 is down regulated in the intestinal epithelia of Crohn's disease patients, and tumour necrosis factor alpha decreases the level of galectin-3-specific mRNA in HCT-8 cells. Eur J Gastroenterol Hepatol, v. I4, n. 2, p. I45-52, 2002.

7. KELLOKUMPU, I.H. et al. Detection of colorectal neoplasm with peanut-agglutinin (PNA) reactive carbohydrate structures in rectal mucus. Int J Cancer, v. 74, n. 6, p. 648-53, 1997.

8. McMAHON, R. F.T. et al. South Asians with ulcerative colitis exhibit altered lectin binding compared with matched European cases. Histochem J, v. 29, n. 6, p. 469-77, 1997.

9. NANGIA-MAKKER, P. et al. Carbohydrate-binding proteins in cancer and their ligands as therapeutic agents. Trends Mol Med, v. 8, n. 4, p. 187-92, 2002.

10. ÖZER, E. et al. Effects of prenatal exposure on neuronal migration, neurogenesis and brain myelinization in the mice brain. Clin Neuropathol, v. 19, n. I, p. 21-5, 2000.
I I. RECTOR,A. et al. Mannan-binding lectin (MBL) gene polymorphisms in ulcerative colitis and Crohn's disease. Genes Immunity, v. 2, n. 6, 323-8, 2001.

12. SAID, I.T. et al. Comparison of different techniques for detection of Gal-GalNAc, an early marker of colonic neoplasia. Histol Histopathol, v. 14, n. 2, p. 351-7, 1999.

I3. SHARON, N.; LIS, H. Carbohydrates in cell recognition. Scientific Amer, v. 268, p. 74-8I, 1993.

I4. SINGH, R. et al. Cell surface-expressed Thomsen-Friedenreich antigen in colon cancer is predominantly carried on high molecular weight splice variants of CD44. Glycobiol, v. I I, n. 7, p. 587-92, 200 I.

15. Van BEMMEL, J. H.; MUSEN, M. A. Biostatistical methods. In: Handbook of medical informatics. Germany: Springer-Verlag (Ed.), 1997. p. 387-96.

16. WRÓBLEWSKI, S. et al. Biorecognition of HPMA copolymerlectin conjugates as an indicator of differentiation of cell-surface glycoproteins in development, maturation, and diseases of human and rodent gastrointestinal tissues.J Biomed Mater Res, v. 5I, p. 329-42, 2000.

17. WRÓBLEWSKI, S. et al. Potential of lectin-N-(2-hydroxypropyl) methacrylamide copolymer-drug conjugates for the treatment of pre-cancerous conditions.J Control Rel, v. 74, p. 283-93, 200 I.

I8.WRÓBLEWSKI, S. et al. The influence of a colonic microbiota on HPMA copolymer lectin conjugates binding in rodent intestine. J Drug Target, v. 9, n. 2, p. 84-94, 200 I.

Mailing address

Eduardo Isidoro Carneiro Beltrãa Laboratório de Imunopatologia Keizo Asam Universidade Federal de Pernambuco Av. Morais Rêgo s/n - Campus Universitário CEP 50670-910 - Recife-PE - Brasil Phone/fax: (81) 3271-8484/3271-8485 e-mail: ebeltrao@hotmail.com 